\title{
24-Rıza Tevfik ve Babanzâde Ahmet Naim arasındaki Tevfik Fikret tartışmasına çok boyutlu bir yaklaşım ${ }^{1}$
}

\section{Mehmet CIHANGÍR²}

APA: Cihangir, M. (2022). Rıza Tevfik ve Babanzâde Ahmet Naim arasındaki Tevfik Fikret tartışmasına çok boyutlu bir yaklaşım. RumeliDE Dil ve Edebiyat Araştırmaları Dergisi, (26), 419430. DOI: $10.29000 /$ rumelide.1073951.

\section{$\ddot{O} \mathbf{z}$}

Türk yazınında önemli isimlerden biri olan Tevfik Fikret’in kişilik özellikleriyle ilgili çok çeşitli görüşler ortaya konulmuştur. Bu kapsamda pek çok örnek sunulabilir. Rıza Tevfik ve Babanzâde Ahmet Naim arasında meydana gelen Tevfik Fikret hakkındaki tartışma da bu bağlamda ele alınabilir. Her iki yazarın Tevfik Fikret üzerine çeşitli açılardan değerlendirme yaptıkları ve yorumda bulundukları görülür. Ancak söz konusu değerlendirme ve yorumların birbirinden farklı yaklaşımlar barındırdığı ve karşıt düşünceler içerdiği tespit edilmiştir. Rıza Tevfik, Tevfik Fikret’i olumlu ifadelerle anlatırken, Babanzâde Ahmet Naim ise Tevfik Fikret’i olumsuz içerik taşıyan sözlerle ifade ettiği ve bu anlamda Rıza Tevfik’le sert bir üslupla tartışmaya girdiği anlaşılır. Bahsi geçen tartışmanın sadece iki yazar arasında ortaya çıkmış ve bitmiş bir konu olmadığı, öncesinde bir arka plan taşıdığı ve sonrasında yapılan benzer münakaşalar üzerinde de etki meydana getirdiği söylenebilir. Bu bağlamda, Rıza Tevfik ile Babanzâde Ahmet Naim arasında cereyan eden Tevfik Fikret tartışmasının, Tevfik Fikret ile Mehmet Akif arasında önceki zamanlarda meydana gelen tartışmadan bağımsız değerlendirilemeyeceği ileri sürülebilir. Hatta söz konusu hususun Osmanlının son dönemlerinde Batılı toplumlarla ilişkisinin bir yansıması olan modern-muhafazakâr, BatıcıDoğucu vb. tabirlerle karşılık bulan münakaşalardan da ayrı ele alınamayacağı ifade edilebilir. Benzer içerik taşıyan tartışmaların bu zamanda da çeşitli alanlarda farklı yazarlar tarafından icra edildiği görülür. Bu durum, konunun ne denli derinlik taşıdığını ve etkiye/etkileşime açık ve çok boyutlu bir özelliğe sahip olduğunu gösterir. Bu çalışmada, Rıza Tevfik ile Babanzâde Ahmet Naim arasında geçen Tevfik Fikret hakkındaki tartışma öncesi ve sonrasıyla ele alınmış ve çeşitli değerlendirmeler ışı̆̆ında konu irdelenmeye çalışılmıştır.

Anahtar kelimeler: Tevfik Fikret, Rıza Tevfik, Babanzâde Ahmet Naim

\section{A multidimensional approach to the discussion on Tevfik Fikret between Riza Tevfik and Babanzâde Ahmet Naim}

\footnotetext{
Abstract

Various opinions have been put forward about the personality traits of Tevfik Fikret, one of important figures in Turkish literature. This is illustrated in many forms. The discussion on Tevfik Fikret between Rıza Tevfik and Babanzâde Ahmet Naim can also be addressed in this context. It is observed that both authors evaluated and made interpretations on Tevfik Fikret from various perspectives. However, it has been determined that these evaluations and interpretations contain different

05-07 Kasım 2021 tarihinde düzenlenen "Güncel Hadis Meseleleri ve Babanzâde Ahmed Naîm Uluslararası Sempozyumu" nda "Rıza Tevfik ve Babanzâde Ahmet Naim Arasındaki Tevfik Fikret Tartışmasına Çok Boyutlu Bir Yaklaşım” başlığıyla sunulan ve özeti bildiri kitabında yer alan çalışmanın genişletilmiş hâlidir.

Dr. Arş. Gör., Dicle Üniversitesi, Edebiyat Fakültesi, Türk Dili ve Edebiyatı Bölümü (Diyarbakır, Türkiye), mehmetcihangir@hotmail.com, ORCID ID: 0000-0002-3894-191X [Araştırma makalesi, Makale kaytt tarihi: 07.01.2022-kabul tarihi: 20.02.2022; DOI: 10.2900o/rumelide.1073951]

Adres | Address

RumeliDE Dil ve Edebiyat Araşttrmalar Dergisi Osmanağa Mahallesi, Mürver Çiçeği Sokak, No:14/8 Kadıköy - İSTANBUL / TÜRKIYE 34714 e-posta: editor@rumelide.com tel: +90 $5057958124,+90216773$ o 616

RumeliDE Journal of Language and Literature Studies

Osmanağa Mahallesi, Mürver Çiçeği Sokak, No:14/8

Kadıköy - ISTANBUL / TURKEY 34714

e-mail: editor@rumelide.com,

phone: +90 5057958124 , +90 2167730616
} 
420 / RumeliDE Journal of Language and Literature Studies 2022.26 (February)

A multidimensional approach to the discussion on Tevfik Fikret between Rıza Tevfik and Babanzâde Ahmet Naim / M. Cihangir (pp. 419-430)

approaches and contrast opinions. While Rıza Tevfik describes Tevfik Fikret in positive terms, Babanzâde Ahmet Naim expresses Tevfik Fikret with negative terms and in this sense, it is well understood that Ahmet Naim has joined the debate using a strong tone against Ruza Tevfik. It can be said that this discussion was not merely a debate between the two authors but also had a background which had an impact on subsequent discussions. In this context, it can be argued that the discussion on Tevfik Fikret between Riza Tevfik and Babanzâde Ahmet Naim cannot be evaluated independently of the previous discussion between Tevfik Fikret and Mehmet Akif. Moreover, it can be stated that this issue cannot be addressed separately from the discussions that corresponded with modernconservative, Western-Orientalist, etc., which reflect the relationship of the Ottoman Empire with Western societies in the last periods. It is observed that discussions with similar content were carried out by different authors in various fields at that time. This indicates how profound the subject is and has multidimensional characteristics with potential impact/interaction. This study encompasses the pre-and-post discussion on Tevfik Fikret between Riza Tevfik and Babanzâde Ahmet Naim and examines the relevant subject in the light of various evaluations.

Keywords: Tevfik Fikret, Rıza Tevfik, Babanzâde Ahmet Naim

\section{Giriş}

Osmanlının girdiği savaşlardan yenilgiler alması, askerî mağlubiyetler yaşaması toprak kayıplarına yol açar ve bu durum devletin küçülmesine neden olur. Böylesi sonuçlar, aynı zamanda kaybedilen topraklardan yoğun göçleri de tetikler ve insanların yaşadıkları yerden zorunlu olarak ayrılmasına kaynaklık eder. Söz konusu meseleler, ülke içinde ve dışında devletin siyasal gücü üzerinde de olumsuz yansımalar meydana getirir ve siyasî bakımdan Osmanlının elini zayıflatır. Kısacası, askerî alandaki başarısızlıklar gerek devlet yöneticilerinin gerekse halkın yaşamı üzerinde olumsuz etkiler meydana getirir ve istenmeyen sonuçlar doğurur. $\mathrm{Bu}$ yüzden Osmanlı ülkesinde çeşitli alanlarda ıslahatlar yapmak, kurumların iyileştirilmesine yönelik eylemlerde bulunmak zorunlu bir ihtiyaç olarak kendisini gösterir. Nihat Sami Banarlı konuya şu ifadelerle dikkat çeker:

"XVI. hatta XVII. asırda dünyanın en üstün siyasi ve askeri kudretini teşkil eden Osmanlı İmparatorluğu, şimdi, ihtiyarlayan bir insan gibi, bütün uzuvlarıyla çöküyordu. Fakat çok büyük bir devlet olduğu için, onun çöküşü de çok uzun sürüyordu. İmparatorluk öylesine büyüktü ki zarif bir Tanzimat diplomatının söylediği gibi, Türkler içeriden, Avrupalılar (hem içeriden hem) dışarıdan yıkmaya çalıștıkları halde onu bir türlü deviremiyorlardı. Fakat dünya tarihini askeri üstünlükleriyle dolduran Türkler’in şimdi üst üste askeri mağlubiyetlere uğrayışı, hem ordunun hem de orduyu sevk ve idare edecek siyasi ve askeri teşkilatın artık ıslah edilmesi lüzumunu meydana koyuyordu" (Banarlı, 1997: 811).

Görüldüğü gibi yazar, Osmanlının zayıfladığını ve zamanla çöküşe doğru gittiğini ifade etmektedir. Devletin zayıflamasında ve çöküşünde hem içerden hem de dışardan aldığı darbelerin önemli bir neden olduğuna vurgu yapmaktadır. Bu durumun askerî ve siyasî alanlarda ıslah edici girişimlerde bulunmayı gerekli kıldığını belirtmektedir. Ancak Osmanlı idarecilerinde, devletin birçok alanında belli bir dönemle birlikte başlayan ve devam eden başarısızlıkların temelinde yapısal sorunların olduğuna ve bunların düzeltilmesi gerektine yönelik tam bir kanaat/inanç olduğu söylenemez. Ramazan Korkmaz konu hakkında şu görüşleri dile getirir: “Osmanlının asıl çıkmazı, 16. yüzyılın ortalarından itibaren askeri, ilmi ve iktisadi sahalarda bozulan kurumlarına yeni bir dinamizm kazandıracak yenilik hamlesini bir türlü yapamayışında, daha da kötüsü, böyle bir hamlenin gereksizliğine inanır hale gelmesinde yatmaktaydı" (Korkmaz, 2007: 16).

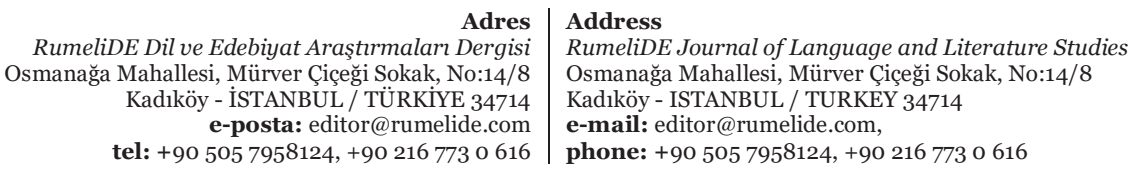


Başarısızlığı kabullenme ve söz konusu sorunu ortadan kaldırma çerçevesinde stratejiler geliştirmek, başarıyı tekrar kazanma adına gerek birey gerekse toplum hayatında mühim bir zorunluluktur. Bir diğer söylemle, başarısızlı̆ı̆ öncelikle kabul edilmesi, başarının gelebilmesi için önem arz eder. Ama -verilen alıntılardan hareketle- Osmanlının belli bir zamana kadar yaşadığı başarısızlıkları kabullenmediği ve bu kapsamda çözüm yollarına girişmediği söylenebilir. Osmanlının aksine Batılı devletlerin bu zaman diliminde askerî açıdan ileri düzeyde gelişim göstermeleri, bilimsel, kültürel, teknolojik ve benzeri bakımdan başarılı çalışmalar ortaya koymaları, onların kendilerini daha güçlü ve donanımlı hissetmelerine kapı açar. Mesela Avrupalı devletlerin Osmanlıyla girdikleri savaşlardan galip ayrılmaları konuyu örneklendirebilir. Osmanlının kendi kurumlarının yozlaştığını ve ıslah edilmesi gerektiğini kabullenmemekle birlikte hem Batılı devletlerdeki gelişmelere kayıtsız kaldığı hem de yer yer bunları olumsuz ifadelerle ötekileştirme yoluna gittiği de ifade edilmektedir. Orhan Okay’nn şu görüşleri konuyu desteklemesi açısından örnek olarak gösterilebilir:

\begin{abstract}
"Batı medeniyeti ile ilk temaslarımız iki asır, hatta biraz daha evveline kadar gider. Lakin Batı edebiyatını tanımamız daha geç olur. 18. Asrın sonuna doğru, devrin reis'ül-küttâbı (dışişleri bakanı) Atıf Efendi, Padişah Üçüncü Selim'e takdim ettiği Muvazene-i Politika (siyasi denge) adlı raporunda, Fransız İhtilali'nden bahsederken 'Ruso ve Volter misillû meşhur zındıkların eserleriyle husule gelmis bir fisk u fücur cümbüsü' diyordu. Batı medeniyetinin teknik, bilhassa askeri sahada üstünlüğünü kabul etmek zorunda kalan 18. asır Osmanlı aydınının hemen bütün Batı düşüncesi ve edebiyatı hakkındaki kanaatleri reis'ül-küttâb efendininkinden fazla farklı değildir” (Okay, 2011: 52).
\end{abstract}

Bu sözlerden, Osmanlı devlet idaresinde Batılı düşüncelere olumsuz bir bakış olduğu şeklinde bir anlam çıkarılabilir. Orhan Okay'ın "ancak 19. asır ortalarında, Tanzimat'tan sonra bu kanaatler değişmeye, daha doğrusu bir takım kanaatler belirmeye başlar. Çünkü Fransızca'dan ilk tercümeler de bu yıllarda görünmeye başlamıştır" (Okay, 2011: 52) ifadesinden hareketle, dönemin devlet idarecileri ve düşünce insanları, söz konusu mağlubiyetleri ortadan kaldırmak, toprak kayıplarıyla devletin küçülmesine engel olmak, göç ve göçleri durdurmak, kısaca başarıyı tekrar yakalamak gibi amaçlarla çeşitli arayışlar içerisine girer ve çözüm üretmeye yönelik çalışmalar başlatırlar. Böyle bir gelişme ise Osmanlının başarısızlı̆̆ kabullendiği ve çözüm aramaya başladığı şeklinde değerlendirmeler yapmayı mümkün kllar.

Böylesi bir durum ise Osmanlıya, Batılı toplumlarla ilişki kurma zorunluluğunu hissettirir. Dolayısıyla Osmanlının Batılı toplumlarla temas kurması, yaşanan kayıplara bir çözüm araştırması, ülkenin içinde bulunduğu çeşitli sorunlara bir çare arayışı olarak açıklanabilir. Nitekim Berna Moran bu ilişkiyi iktisadî ve siyasî zayıflamanın gerektirdiği bir zorunluluk olarak görür ve bu yüzden devletin kendini Batı'ya uydurmak zorunda kaldığına dikkat çeker. Böylece Osmanlının yönetimde, eğitimde, hukukta dinî esaslara dayalı olan kendi düzenine yabancı bir istikamette ıslahatlara girişmesinin kaçınılmaz olduğuna vurgu yapar (Moran, 2012: 21).

Moran'ın da belirttiği gibi Osmanlının yaşadığı sorunlardan kurtulması ya da var olan sıkıntıları en aza indirmesi için reformlar yapması zorunlu bir durumdur. Çünkü her geçen zaman Osmanlı birçok alanda kayıplar yaşamakta ve bu kayıplar hem devlet idarecilerini hem de Osmanlı toplumunu daha fazla sıkıntılarla boğuşmak zorunda bırakmaktadır. Dolayısıyla Osmanlının, Batılı devletlerin ilerleme modellerinden yararlanmak ve bu modelleri kendine de uyarlamak mecburiyetinde kalmıştır denilebilir. Böylece bu dönemde Osmanlı ile Batı arasında cereyan eden ilişkinin faydacı bir yaklaşım barındırdığı söylenebilir. Nitekim İlber Ortaylı da söz konusu zamandaki Osmanlı - Batı ilişkisini "pragmatik bir yaklaşım” biçimi olarak değerlendirir (Ortaylı, 2009: 27). Zaten bir zaman sonra bahsi geçen durumun örnekleri Osmanlıda görülmeye başlanır. Konuyla ilişkili olarak Kenan Akyüz şöyle bir değerlendirme yapar:

Adres

RumeliDE Dil ve Edebiyat Araştırmalar Dergisi Osmanağa Mahallesi, Mürver Çiçeği Sokak, No:14/8 Kadıköy - İSTANBUL / TÜRKIYE 34714 tel: $+905057958124,+002167730616$
Address

RumeliDE Journal of Language and Literature Studies

Osmanağa Mahallesi, Mürver Çiçeği Sokak, No:14/8

Kadıköy - ISTANBUL / TURKEY 34714

e-mail: editor@rumelide.com,

phone: +90 $5057958124,+902167730616$ 
422 / RumeliDE Journal of Language and Literature Studies 2022.26 (February)

A multidimensional approach to the discussion on Tevfik Fikret between Rıza Tevfik and Babanzâde Ahmet Naim / M. Cihangir (pp. 419-430)

\begin{abstract}
“Osmanlı İmparatorluğu'nun yükseliş grafiği, XVI. asrın sonlarında aşağıya doğru inmeye başlamıştı. XVII. asırda gittikçe hızlanan bu iniş, Karlofça (1699) ve Pasarofça (1718) andlaşmaları ile en ağır şekilde belgelendikten sonra, İmparatorluğun yöneticileri, o zamana kadar yalnız savaş ve kısmen de ticaret konularının dışında Batılılarla hiçbir temas kurmama alışkanlığını bir kenara bırakmak ve daha çok askeri mağlubiyetlerin önünü alabilmek için- onları yakından tanımak ve yararlanmak ihtiyacını duydular ve ilk adımı attılar. Bu ilk adım, Osmanlı tarihinde Lale devri (1718-1730) diye anılan dönemde XV. Lous'in tahta çıkışını kutlamak için Fransa’ya gönderilen (Ekim 1720) Yirmi Sekiz Mehmed Çelebi’nin yaptığı ziyarettir” (Akyüz, 1995: 5).
\end{abstract}

Verilen alıntıdan hareketle Osmanlıyı, Batılı ülkelerle temas kurmaya iten asıl saikin yaşanan kayıpların -özellikle askerî alanda- önüne geçmek olduğu ileri sürülebilir. Böylece Avrupa'ya çeşitli amaçlarla kişi ve kişiler gitmeye/gönderilmeye başlanır. Bu yöneliş, Osmanlının Batılı milletlerle olan temas düzeyini artırır ve devletin rotasını Doğu'dan Batı'ya döndürmesi olarak da açıklanabilir. Böyle bir ilişki aynı zamanda doğrudan ya da dolaylı olarak sosyal, siyasal, kültürel vb. anlamda Batılı fikirlerin Osmanlı toplumu içerisine akmasına ve yer edinmesine kaynaklık eder.

Burada şu detayın altını çizmek gerekir. Birey ve toplum yaşamında etkileşim olmazsa olmaz bir öneme sahiptir. Sosyal bir varlık olan insanın gelişebilmek için başka insanlarla ilişki kurması gerektiği gibi toplum ve devletlerin de farklı toplum ve devletlerle temasta bulunmaları ilerleme kaydedebilmeleri için önemli bir zorunluluktur. Esasen tarihsel sürece bakıldığında her milletin bir başka milletten alımlamalar yapmak suretiyle kazanımlar sağladığı, bilimin, sanatın, kültürün böylelikle gelişim kaydettiği söylenebilir. Mesela, Abbasi Hanedanlığı zamanında Batı karanlık bir dönem yaşarken, Bağdat'ın önemli bir medeniyet merkezi olduğu bilinmektedir. Dokuzuncu yüzyılın ortalarında Bağdat'taki Beyt'ül Hikmet (Hikmet Evi) kütüphanesinde alimler; Aristo, Platon, Öklit, Batlamyus, Hipokrat ve Kalinos gibi düşünürlerin eserleri üzerine çalışmalar yaptıkları ifade edilmektedir (Davişa, 2004: 70).

Yapılan bu çalışmaların, Batılı toplumların Doğulu milletlerle çeşitli vesileler3 üzerinden ilişki kurmalarının bir sonucu olarak tekrar Batıya aktığına Amin Maalouf şöyle işaret eder: "Eski Yunan uygarlığının mirası Batı Avrupa'ya ancak çevirmen ve şerh edici Araplar aracılığıyla aktarılabilirdi. Frenkler, tıp, astronomi, kimya, coğrafya, matematik, mimari alanlarındaki bilgilerini Arapça kitaplardan edinmişler; bu kitapları özümlemişler, taklit etmişler, sonra aşmışlardır" (Amin Maalouf, 1998: 338-339). Dolayısıyla, tarihsel süreç içerisinde her bir milletin farklı çalışmalar yoluyla bilimin, kültürün gelişimine katkı vermiş olduğu ve böylesi kazanımların toplumlararası/milletlerarası ilişki yoluyla tüm insanlığa getiri sağladığı söylenebilir. Ayrıca ilişki kurulması, muhatabın her özelliğinin olduğu gibi benimsenmesi anlamına gelmez.

Osmanlının çeşitli gerekçelerle Batılı ülkelerle temaslar kurması, devletin gelişimi ve milletin yaşam koşullarının iyileşmesi adına önem arz eder. Böylelikle devlet hem Doğu hem de Batı’yla ilişkide bulunmuş olur. Fakat bu münasebetler, Doğulu fikirlerin yanı sıra Batılı düşüncelerin de Osmanlıya nüfuz etmesine yol açar. Söz konusu durum ise -her ne kadar kültürel zenginliğe ve çeşitliliğe yol açsa da- aynı zamanda Osmanlı toplumunda ayrışmalara da kapı açar. Mesela, Batılı devletlerdeki edinimlerini Osmanlının yaşadığı sorunlara çözüm yolu olarak görenler tarafından dile getirilen çeşitli görüşlerin, yerleşik ya da Doğu kaynaklı fikirleri savunan kimseler tarafından sert eleştirilere uğradığı bilinmektedir. Nitekim Osmanlı içerisinde bu çerçevede tartışmaların meydana geldiği belirtilmektedir. Ahmet Hamdi Tanpınar konuya şöyle vurgu yapar:

Bu bağlamda “Haçlı Seferleri”"nin önemli bir vesile olduğu ileri sürülebilir. Söz gelimi, Vasili Viladimiroviç Barthold’a göre Haçlı Seferleri Avrupalılara İslam kültürüyle tanışma imkânı sağlamıștır” (Barthold, 2004: 113).

Adres $\mid$ Address

RumeliDE Dil ve Edebiyat Araştırmaları Dergisi Osmanağa Mahallesi, Mürver Çiçeği Sokak, No:14/8 Kadıköy - İSTANBUL / TÜRKIYE 34714 e-posta: editor@rumelide.com tel: +90 5057958124, +902167730616

RumeliDE Journal of Language and Literature Studies

Osmanağa Mahallesi, Mürver Çiçeği Sokak, No:14/8

Kadıköy - ISTANBUL / TURKEY 34714

e-mail: editor@rumelide.com,

phone: +90 $5057958124,+902167730616$ 


\begin{abstract}
“1839'dan sonraki devrin bir hususiliği de memlekette gittikçe kuvvetini artıran bir ikiliği doğurması onun ruh ve manzara ve ruh bütünlüğünü kırmasıdır. Bugün bile halk dilinde ve hatta fikir hayatında o zamanlardan kalan 'alafranga' ve 'alaturka' (mûsiki de olduğu gibi), 'eski' ve 'yeni' (zihniyet meselelerinde) tabirleriyle ifade edilen bu ikilik realitesi Tanzimat'in en büyük fatalitesidir" (Tanpınar, 2001: 136).
\end{abstract}

Yazar, Osmanlı toplumunda 1839 yılı sonrasında yaşanan ikili anlayış biçiminin, sonraki zamanlarda da devam ettiğine dikkat çekmektedir. Benzer bir saptamanın C. Ernest Dawn tarafından da yapıldı̆̆ görülür: "Vatanseverlik, milliyetçilik, Osmanlıcılık ve Arapçılık, modernlik ve geri kalmışlık gibi kavramlar, Osmanlı İmparatorluğu’ndaki siyasi sınıflar açısından Avrupa ile girilen ilişkinin bir sonucu olarak tartışmalı kavramlar oluvermişlerdi” (Dawn, 1998: 199). Dolayısıyla Batı'yla olan temaslar, Osmanlıya çeşitli kazanımlar sağlamanın yanında toplum içerisinde birbirine muhalif ikili akımların ortaya çıkmasına da kaynaklık etmiştir denilebilir. Nitekim söz konusu durumun bu zamanda bile varlığını sürdürdüğ̈̈ ileri sürülebilir. Osmanlı toplumunda yaşanan ikili anlayışın, bahsi geçen dönemde diğer Müslüman toplumlarda da var olduğu tespit edilmiştir (Ortayll, 2009: 13-15). İbrahim Ebu Rabi'nin eserinde dile getirdiği açıllama konuya şöyle ışık tutar:

\begin{abstract}
“Arap entelijensiyasının, bir yandan modern, öbür yandan ise selefi olmaktan kaynaklanan düalist yapısı, modern Arap düşüncesinde gelenekçilik ve çağdaşlık problematiğinin doğmasına neden oldu. Düşüncede, eylemde, bakış açısında ve hatta kurumlarda düalizm, çağdaş Arap dünyasında günümüzün damgası oldu" (Ebû-Rabi, 2005: 33).
\end{abstract}

Görüldüğü gibi bahsi geçen durumun Arap toplumu içerisinde de etkinlik kazandı̆̆ı ve bu zamanda bile devam ettiği anlaşılmaktadır. Konunun sosyolojik, psikolojik vb. boyutları göz önüne alındığında, yüzlerce yllık geçmişi olan, toplum içerisine yerleşmiş ve tabu halini almış düşünceleri birden bire ortadan kaldırmanın ve yerlerine yeni şeyler ikame etmenin kolay olmayacağı muhakkaktır. Bu yüzden, Batı'daki gelişmeleri doğrudan Osmanlı ve Arap toplumuna kanalize etmeye yönelik çabaların, yerleşik düzeni savunan ve korumak isteyenler tarafından engellenmesi kaçınılmazdır.

\title{
Rıza Tevfik ve Babanzâde Ahmet Naim arasındaki Tevfik Fikret tartışmasına çok boyutlu bir yaklaşım
}

Türk yazınında önemli isimlerden biri olan Tevfik Fikret’in kişilik özellikleriyle ilgili çok çeşitli düşünceler ortaya konulmuştur. Bu bağlamda birçok örnek verilebilir. Rıza Tevfik ve Babanzâde Ahmet Naim arasında meydana gelen Tevfik Fikret hakkındaki tartışma da bu bağlamda ele alınabilir. Her iki yazarın Tevfik Fikret üzerine değişik açılardan değerlendirme yaptıkları ve yorumda bulundukları saptanmıştır. Ancak söz konusu değerlendirme ve yorumların birbirinden farklı yaklaşımlar barındırdığı ve karşıt düşünceler içerdiği tespit edilmiştir. Rıza Tevfik, Tevfik Fikret’i olumlu ifadelerle anlatırken, Babanzâde Ahmet Naim ise Tevfik Fikret’i olumsuz içerik taşıyan sözlerle ifade ettiği ve bu anlamda Rıza Tevfik'le sert bir üslupla tartışmaya girdiği anlaşılır.

Bahsi geçen tartışmanın sadece iki yazar arasında ortaya çıkmış ve bitmiş bir konu olmadığı, öncesinde bir arka plan taşıdığı ve sonrasında yapılan benzer münakaşalar üzerinde de etki meydana getirdiği söylenebilir. Bu bağlamda, Rıza Tevfik ile Babanzâde Ahmet Naim arasında cereyan eden Tevfik Fikret tartışmasının, Tevfik Fikret ile Mehmet Akif arasında önceki zamanlarda meydana gelen tartışmadan bağımsız değerlendirilemeyeceği ileri sürülebilir. Hatta söz konusu hususun Osmanlının son dönemlerinde Batılı toplumlarla ilişkisinin bir yansıması olan modern-muhafazakâr, Batıcı-Doğucu vb. tabirlerle karşılık bulan münakaşalardan da ayrı ele alınamayacağı ifade edilebilir.

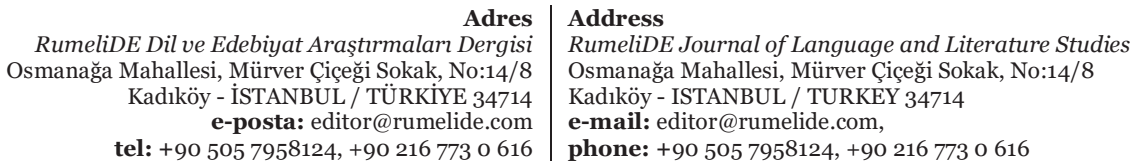


Benzer içerik taşıyan tartışmaların bu zamanda da çeşitli alanlarda farklı yazarlar tarafından icra edildiği görülür. Bu durum, konunun ne denli derinlik taşıdığını ve etkiye/etkileşime açık ve çok boyutlu bir özelliğe sahip olduğunu gösterir. Bu çalışmada, Rıza Tevfik ile Babanzâde Ahmet Naim arasında geçen Tevfik Fikret hakkındaki tartışma öncesi ve sonrasıyla ele alınmış ve çeşitli değerlendirmeler ışığında konu irdelenmeye çalışılmıştır.

\title{
Tevfik Fikret - Mehmet Akif tartışması
}

Rıza Tevfik'le Babanzade Ahmet Naim arasında gerçekleşen söz konusu tartışmanın arka planında Tevfik Fikret'le Mehmet Akif arasında cereyan eden münakaşanın yattı̆̆g söylenebilir. Pek çok düşünürün bahsi geçen tartışma hakkında görüş dile getirdikleri tespit edilmiştir. Söz gelişi, her iki edip arasındaki tartışmayı "kavga" olarak nitelendiren Kenan Akyüz, bu münakaşanın temelinde Osmanlının yaşadığı sorunlara çözüm arayışının yattığını ifade eder. Yazar hem Mehmet Akifin hem de Tevfik Fikret’in bu konuda aynı görüşü paylaştıklarını, ama onların söz konusu sıkıntıların çözümü için kullanılacak yol ve yöntem bakımından birbirinden ayrıldıklarını ve farklı yaklaşımlar sergilediklerini belirtir. Akyüz, konuyu biraz daha detaylandırır ve onların farklı yaklaşım sergilemesinde temel noktanın din ve inanç boyutu taşıdığını vurgular. Her iki yazarın düşünsel açıdan farklı görüşler ortaya koymalarını normal bir durum olarak gören Akyüz, onların bu anlaşmazlıklarını kavgaya dönüştürmelerini gerektirecek bir durum olmadığına dikkat çeker (Akyüz, 1947: 128-129). Bu tartışmayla ilgili olarak Atilla Özkırımlı da "kavga" ifadesini kullanır ve çalışmasında konuyu geniş bir perspektiften değerlendirir:

\begin{abstract}
"Edebiyat tarihlerine "Tevflk Fikret - Mehmet Akif kavgası” biçiminde yansıyan düşünce çatışmasını, bir edebiyat tartışması olarak görmemek gerekir. Ne bir dil ve biçim anlaşmazlığı ne içerik'e değgin bir yenilik ve ne genel olarak yazınsal bir sorun yol açmıştır bu kavgaya. Üstelik çatışma belli bir zaman süresinde olmuş bitmiş de değildir. 1912'de başlamıştır ama tohumları çok önceden atılmıştır, iki şairin ölümünden sonra yandaşlarınca sürdürüldüğü gibi, günümüzde de yaşarlığını yitirmemiş, giderek bir ilerici - gerici kavgasının simgesi durumuna getirilmiştir. Tartışma değil de kavga sözcüğüyle nitelenmesi bile bu çatışmanın niteliğini yeterince açıllamaktadır. Tek cümleyle söylemek gerekirse, iki şairin adına bağlanan bu kavga, değişik dünya görüşlerine sahip grupların çatışmasından başka bir şey değildir” (Özkırımlı, 1987: 103).
\end{abstract}

Görüldüğü gibi Özkırımlı, Tevfik Fikret’le Mehmet Akif arasında gerçekleşen o dönem tartışmalarının önemli bir arka plana sahip olduğuna dikkat çeker. Dolayısıyla konu -önceki satırlarda da vurgulandığı üzere- Doğu-Batı, Doğulu-Batılı şeklinde kavramlarla ifade edilen yaklaşımlar çerçevesinde açıklanabilir. Nitekim bahsi geçen tartışma, sadece bu iki düşünürle de sınırlı kalmamış, dostları ve takipçileri tarafından da sürdürülmüştür. Mehmet Kaplan, bu meseleye şu sözlerle vurgu yapar: "Fikret'in bu şiiri, dindar bir şair olan Akif'e çok çarpmış, bu münasebetle Fikret'le Akif arasında, ikisini sevenlerin de katıldığı, şiddetli bir kalem münakaşası olmuştur” (Kaplan, 1986: 27).

Rıza Tevfik ile Babanzade Ahmet Naim arasında meydana gelen Tevfik Fikret hakkındaki tartışma da bu bağlamda değerlendirilebilir. Tevfik Fikret'le ilgili verdiği bir konferansta Rıza Tevfik’in dile getirdiği görüssler, Babanzâde Ahmet Naim tarafından "Tevfik Fikret'e Dair Filozof Doktor Rıza Tevfik Beyefendiye" başlı̆̆ı taşıyan bir yazı üzerinden sert bir dille eleştiriye uğrar. Söz konusu eleştiri yazısının, Tevfik Fikret'le ilgili daha sonraki zamanlarda farklı düşünürler tarafından kaleme alınan yazılarda da referans olarak verildiği görülür. Bu bağlamda bahsi geçen yazıyı olumlu bulup takdir edenler kadar olumsuz bulup eleştirenlerin de bulunduğu saptanmıştır. Esasen her iki düşünür, Tevfik Fikret’le çok yakın mesai yaptıklarını ve onu çok iyi tanıma fırsatı bulduklarını belirtirler. Mesela Rıza Tevfik, Tevfik Fikret hakkında yaptığı çalışmanın nedenini anlatırken bu yakınlı̆̆a da vurgu yapar:

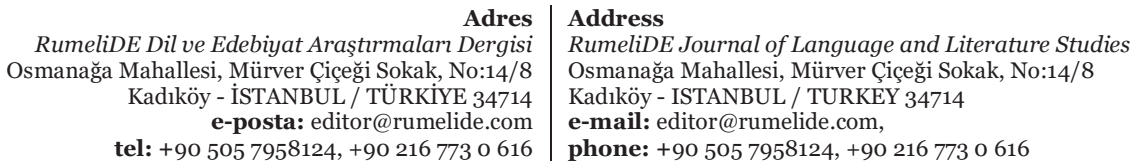




\begin{abstract}
"Memleketimizin ve gençliğin hem muhlis hizmetkârları, hem de velinimetleri olan büyük adamlarını o gençliğe hakkiyle tanıtmak, (o büyük adamlara hürmet ve yetişecek gençlere hizmet) borcudur. Merhum şairin hayatını, mâneviyetini, mizacını, seciyesini ve eserlerini bilen yakın dostlarından biri olmak haysiyetiyle övünebileceğim için, tercümei halini - mazbut ve etraflıca bir surette yazmak hizmetini (onun aziz hatırasına hürmeten) üzerime aldım” (Rıza Tevfik, 1945: 3-4).
\end{abstract}

Verilen alıntıdan da anlaşılacağı üzere Rıza Tevfik, Tevfik Fikret’le olan yakın dostluğunun, onu iyi tanımasına kaynaklık ettiğini dile getirir ve Tevfik Fikret hakkında sahip olduğu bilgileri toplumla, özellikle gençlerle paylaşmayı önemli bir vazife olarak görür. Aslında bu satırlarda yazarın genel anlamda bir yaklaşım sergilediği söylenebilir. Böylelikle Rıza Tevfik, içinde büyüdüğü toplum üzerinde emeği olan insanları topluma anlatmanın gerekli olduğunu dile getirmekte ve yakından bildiği Tevfik Fikret’i gençliğe, yetişen kuşağa tanıtmanın bir görev olduğunun altını çizmektedir.

Yazarın, Tevfik Fikret’i topluma anlatmasının bir diğer nedeni ise onun hakkında yapılan dedikodulardır: "Lâkin bu talihsiz şairi hali ihtizarında fena halde bîzar ve rahatsız eden dedikodulara karşı - vefatından sonra bile müdafaa etmek mecburiyetinde bulunmuş olduğumdan dolayı,- gençlerin laykkiyle bilmediği bazı cihetler hakkında izahat vermeğe lüzum gördüm de o sebeple bu sayfaları yazdım" (Rıza Tevfik, 1945: 4). Babanzâde Ahmet Naim de Tevfik Fikret’ten bahsederken, onunla on beş yıl birlikte çalıştığını ve onu yakından tanıdığını şu sözlerle belirtir:

"Fikret ile benim Galatasaray Sultanîsi heyet-i tedrîsiyesi içinde on beş senelik refâkatim ve ahvâline iyice ıttılâım vardır. Nükte-perdâz, hoş sohbet, savti âhenkdâr ve müessir, sâmiini meshur edecek bir hüsn-i beyana sahip, her nerede bulunsa etrafinda bir halka-i müstemiîn çevirtecek mıknatısîyeti hâiz bir zât idi. Bugünkü genç perestişkârlarının üç dört sene evvelki manasız inkârları hilâfına olarak büyük bir şairdi” (Babanzâde Ahmet Naim, 2018: 564).

Babanzâde Ahmet Naim, Tevfik Fikret'le on beş sene birlikte çalıştığını, onun hoş sohbet, samimi bir kişiliğe sahip ve büyük bir şair olduğunu dile getirmektedir. Dolayısıyla her iki düşünür, Tevfik Fikret'le yakın ilişkiler içerisinde bulunduklarını ve bu ilişkiye dayanarak Tevfik Fikret’i yakından tanıdıklarını ifade etmektedirler. Fakat bahsi geçen yazarlar her ne kadar Tevfik Fikret’i yakından tanıdıklarını belirtseler de onunla ilgili dile getirdikleri tespit ve izlenimlerinde birbirleriyle çeliştikleri görülür. Mesela Rıza Tevfik, Fikret’in dostluğa çok yüksek kıymet verdiğine, bu yüzden dostlarının az ama çok değerli insanlardan oluştuğuna dikkat çekerken (Rıza Tevfik, 1945: 17), Babanzâde Ahmet Naim ise Tevfik Fikret'in dostluk anlayışı hakkında şöyle bir açıklama yapar:

"Birçok kimseleri en ufak taksirlerinden dolayı gayet şenî‘ bir surette zemmettiğini kulağımla duydumsa da velev bir kimsenin medhini ağzından ișittiğime dair eda-yı şehadete imkân bulamam. Ağzında insanlığın vâkıâ kıymeti pek büyük idi. Fakat o vasfi hâiz mevcut henüz dünyaya gelmemişti. Daha doğrusu o mevcud-ı yegâne kendisi idi” (Babanzâde Ahmet Naim, 2018: 564).

Bu satırlarda Babanzâde, Tevfik Fikret’i çevresindeki kimseleri ağır sözlerle kötüleyen, onlar hakkında herhangi bir övücü yaklaşımda bulunmayan bir kimse olarak ifade etmektedir. Onun insana kıymet verdiği şeklinde sözler kullanmasına rağmen bahsini ettiği özellikte bir kişinin henüz dünyaya gelmemiş olduğunu, aslında bu ifadeyle Fikret’in kendisini kast ettiğini belirtmektedir. Dile getirdiği sözlerden hareketle Babanzâde’nin, Tevfik Fikret'e yönelik olumsuz bir bakış açısı taşıdığı söylenebilir. Yazar, Fikret hakkında sergilediği olumsuz yaklaşımını eserinde şu sözlerle sürdürür.

"Maa-hâzâ Mekteb-i Sultanî müdiriyetinden infisâli gününe kadar kendisi ile görüştüğüm halde hatır- şikenâne bir muamelesine de maruz kalmadım. Kalmayışım da birinci derecedeki samimi dostları sırasına girmekten ihtirâzımın berekâtındandır. Zira görüyordum ki, vefalı yârânından dilgîr etmedik, daha doğrusu dil-gîr olmadık kimse bırakmıyor" (Babanzâde Ahmet Naim, 2018: 564).

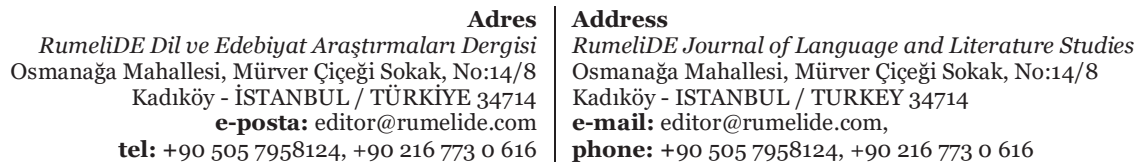

RumeliDE Dil ve Edebiyat Araştırmaları Dergisi Kadıköy - İSTANBUL / TÜRKIYY 34714 tel: $+905057958124,+902167730616$
Address

RumetiDE Journal of Language and Literature Studies

Kadıköy - ISTANBUL / TURKEY 3471

phone: +90 505 7958124, +902167730616 
Görüldüğü gibi Babanzâde, Tevfik Fikret’i olumsuz ifadelerle doğrudan eleştiriye tabi tutmaktadır. Dolayısıyla Rıza Tevfik ile Babanzâde'nin, Tevfik Fikret’i yakından tanıdıkları, onunla yakın ilişkiler içerisinde bulundukları anlaşılmaktadır. Fakat Rıza Tevfik, bu yakınlıktan hareketle, onun kişilik özelliklerini takdir dolu sözlerle anlatırken, Babanzâde Ahmet Naim’in ise bazı istisna sözler hariç Fikret'i olumsuz tabirlerle ifade ettiği söylenebilir.

\title{
İki yazarın Tevfik Fikret'e inanç yönünden bakışı
}

Rıza Tevfik ile Babanzâde Ahmet Naim’in ayrılığa düştükleri asıl konu Tevfik Fikret’in inanç yönüdür. Bu bağlamda her iki yazarın birbirine ters düştükleri, hakarete varan ifadelerle tartışmaya girdikleri tespit edilmiştir. Rıza Tevfik, Tevfik Fikret'in inanç yönünden karmaşık duygular içerisine düştüğüne vurgu yapar. Onu hakkıyla anlamak/anlayabilmek için şiirlerinin derinlikli analiz edilmesi gerektiğine dikkat çeker: "Fikret - şiirleri sathi bir nazarla anlaşılır adamlardan değildir. Ben bu adamı, sayın okuyucularıma, iyice tanıtmak icin eserlerinden misal getirmeyi daha ziyade maksadıma muvafik buldum” (Rıza Tevfik, 1945: 44).4 Yazar sözlerini şöyle sürdürür:

"Çok daha evvel (Köyün mezarlığında) adlı şiirinde, Allaha çok dindarane bir lisanla hitap ederek mağfiretinin ve rahmetinin hikmetini sormak için: (Nedir hakikati ey surrı ekberi mescût!) Bu derecede dindarâne ve edibâne bir lisan ile hitap eden ve mağfiretinden müjdeler alan Fikret değil miydi? O güzel şiirin nihayetini dikkatle okuyunuz; tam bir müslüman vicdanına inen lem'ai ilhamı derhal tanıyabilirsiniz" (Rıza Tevfik, 1945: 49).

Verilen alıntıdan da anlaşılacağı üzere Rıza Tevfik, Tevfik Fikret’in şiirinden alıntı yapmak suretiyle onun inanç yönünü açıklamaya çalışmaktadır. Rıza Tevfik tarafından kaleme alınan eserin bir başka sayfasında yapılan açıklamalara göre çevresinde bulunan bazı insanlar ve dönemsel koşullar, Tevfik Fikret'in sıkıntılı ruh haline girmesinin asıl nedenidir. Hatta yazarın bahsi geçen sayfada dile getirdiği sözlerinden, bulunduğu çevrede maruz kaldığı tutum ve davranışların onu sadece inanç yönünden etkilemekle kalmayıp umudunu yitirmesine, karamsar olmasına ve insanlardan uzaklaşmasına yol açttğı anlaşılmaktadır (Rıza Tevfik, 1945: 45). Rıza Tevfik, söz konusu çevrenin yaptığı baskının Fikret üzerinde bıraktığı olumsuz etkiye çeşitli söylemlerle vurgu yapmaya devam eder:

\begin{abstract}
"Bizde böyle (bir faziletli adam nümunesi aranılırsa Fikretten iyisi bulunamaz. Ben zannediyorum ki, eğer bu muhlis ve san'atkar adamcağız Serveti Fünundaki mevkiinde ve pek sevdiği edebiyat meşgalesinde ihtiyar olunciya kadar kalabilseydi, (yani müstebit ve ziyankar bir hükûmetin ve müfsid, pis bir muhitin, her ümidi öldüren tecavüzlerinden, müdahalelerinden azade olabilseydi), feyyaz tabiatinin inkişafina mani olan maddi, manevi, siyasi ve içtimai amillerle her adım başında göğüs gögüse mücahedeye mecbur bulunduğunu ve nihayet mağlup olduğunu ve en tatll ve sevgili emellerini bu yolda kurban verdiğini gözüyle görmeseydi, çok nikbin ve hattâ mümin olur ve çok yaşardı hem daha çok eserler vücuda getirirdi” (Rıza Tevfik, 1945: 43-44).
\end{abstract}

Verilen alıntıdan, Tevfik Fikret’in sosyal ve siyasal pek çok taraftan baskıya maruz kalmış olduğu anlaşılmaktadır. Böylesi baskılara maruz kalmış olmasının, onun hem inancına hem de yazınsal üretkenliğine zarar verdiği görülmektedir. Nitekim yazar, Fikret’in şiirinde içine girdiği bunalımlı durumuna kendisinin de dikkat çektiğini ifade eder:

"O kadar merhametli, o kadar insaniyetperver, o kadar sevmeğe müstait gönüllü yaratılmış olan Fikret, kendisini hayatından bezdiren, bir firkaya karşı - ve yanlış olarak - bütün insanlardan iğrendikten (ve hele kahır yüzünden ye'se düşüp ruhan ve bedenen hasta olduktan sonra) muhitinden

4 Medine Sivri ve Halil Özdemir tarafından yapılan “Victor Hugo ve Tevfik Fikret’in Çocuk Temalı Şiirlerine Karşılaştırmalı Bir Bakış" başlıklı bir çalıșmada da Tevfik Fikret’i anlamak için onun yaşadığı dönemi, okuduğu ve kaleme aldığı eserleri, tanıştığı ve etkilendiği kişileri karşılaştırmalı bir şekilde incelemenin gerekli olduğuna vurgu yapılmaktadır (Sivri ve Özdemir, 2021: 14). Böylesi değerlendirmelerden, Tevfik Fikret’i anlamak için çok taraflı bir yaklaşım sergilenmesi gerektiği anlaşılmaktadır.

RumeliDE Dil ve Edebiyat Araştırmaları Dergisi Osmanağa Mahallesi, Mürver Çiçeği Sokak, No:14/8 Kadıköy - İSTANBUL / TÜRKIYE 34714 e-posta: editor@rumelide.com tel: +90 $5057958124,+902167730616$
Address

RumeliDE Journal of Language and Literature Studies

Osmanağa Mahallesi, Mürver Çiçeği Sokak, No:14/8

Kadıköy - ISTANBUL / TURKEY 34714

e-mail: editor@rumelide.com,

phone: +90 505 7958124, +902167730616 
ayrı yaşamağa mecbur olmuş, insanlardan uzaklaşmış, onları hor ve hakir görmüş ve bunu (Heykeli sâiy) ünvanlı şiirinde açıç̧a söylemiştir” (Rıza Tevfik, 1945: 53-54).

Rıza Tevfik, maruz kaldığı çevre baskılarının Fikret’in inancına, yazınsal üretkenliğine zarar verdiği gibi aynı zamanda onun toplumdan uzaklaşmasında, ruhen ve bedenen hastalanmasında da önemli bir neden olduğuna vurgu yapar. Hatta yazar, onun genç yaşta ölümünden bile çevresinde bulunan bazı kimselerin payı olduğu görüşündedir: "Benim anladığıma göre yeis onu dinden, imandan çıkarmıştır ve altı sene bile sürmeyen Serveti Fünun hayatının izmihlali yalnız dinine imanına zarar vermekle kalmamıştır; henüz genç yaşında iken feci bir suretle ölümüne de sebep olmuştur" (Rıza Tevfik, 1945: 44).

Rıza Tevfik, ölümünden hemen sonra henüz defin öncesi, ölüm yatağında bulunan Tevfik Fikret’e Robert Koleji’nin müdürü tarafından bir ziyaret gerçekleştirildiğini söyler. O, bu ziyaret esnasında müdürün gözyaşları içinde "Fikret Beye çok yazık oldu. Bir büyük adamdı. Onu muhiti telef etti!" şeklindeki sözlerle hislerini dile getirdiğini ifade eder (Rıza Tevfik, 1945: 61). Bu açıklamalardan, Tevfik Fikret'in içine girdiği olumsuz ruh halinin sorumluları, çevresinde bulunan bazı kimseler olduğu anlaşılmaktadır. Nitekim Rıza Tevfik de bu konuda düşüncelerini doğrudan dile getirir:

\begin{abstract}
"Böyle hamiyetli, muhlis bir kıymetli şairi en sonra gördüğümüz zavallı Fikret haline sokanlar kimler ise, Fikretin bütün günahları onlara racidir. Bence me'yusiyyet yüzünden şehit olan- hamiyetli, faziletli ve insaniyetli Fikret, ne dediyse mâzurdur. Onun küfrü, kendisinin bütün fedakârlığına karşı, - halktan değil! - bir firkadan ve ancak o firkayı temsil eden o zamanki hükûmetten - görmüş olduğu küfranı nimetin aksi sadasıdır" (Rıza Tevfik,1945: 49-50).
\end{abstract}

Rıza Tevfik’in Tevfik Fikret hakkında ortaya koyduğu ifadelerin olumlu bir yaklaşım barındırdığı söylenebilir. Yazar, Fikret'in yaşadığı sıkıntıların kendisinden kaynaklanmadığını, bulunduğu çevrenin onda böylesi sorunların meydana gelmesine neden olduğunu vurgulamaktadır. Babanzâde Ahmet Naim'in Tevfik Fikret'e bakış açısının böyle olmadığı, bir diğer ifadeyle, Babanzâde'nin Tevfik Fikret hakkında olumsuz yaklaşım barındıran cümlelerle değerlendirme yaptığı söylenebilir. Önceki satırlarda da altı çizildiği üzere Babanzâde Ahmet Naim, "Tevfik Fikret'e Dair Filozof Doktor Riza Tevfik Beyefendiye" başlıklı çalışmasında Tevfik Fikret'le ilgili doğrudan görüşler dile getirmemektedir. O, Rıza Tevfik'in Tevfik Fikret hakkında verdiği bir konferansta beyan ettiği görüşleri sert bir üslupla eleştirmektedir. Ancak her ne kadar yazar değerlendirmesinde, Rıza Tevfik'e cevap verme gereği üzerinden hareket ettiğini belirtmiş olsa da Tevfik Fikret’i anlatırken ağır bir üslup kullandığı görülmektedir. Söz gelişi Babanzâde, Tevfik Fikret'in inancı hakkında görüşlerini paylaşan Rıza Tevfik'le şöyle bir tartışmada bulunur:

"Fikret'in fikir ve akîdesini, mü’minliğini, fezâil-i ahlâkta pîşrevliğini izah ve ispat vazife-i müşkilesini hasbe'r-refâka zât-ı âlîleri deruhte buyurdunuz. Malum olan hüsn-i beyanınızla beraber ne dereceye kadar muvaffakiyet göstereceğinizi bilmiyorum. Fakat sorarım, bu kadar zahmete, külfete hâcet var mıydı? Âsârı meydanda duran, etvârı mahfaza-i hayalimizden silinmeyen, tanîn-i sureti kulağımızda hâlâ çınlayan dünkü, daha doğrusu bugünkü Fikret'in imanını ispata muhtaç görmek bi-nefsihî onun aleyhine beyyine değil midir?” (Babanzâde Ahmet Naim, 2018: 563)

Görüldüğü gibi yazar, Tevfik Fikret’in inancıyla alakalı Rıza Tevfik'in görüşlerine olumsuz bir yaklaşım sergilemektedir. Hatta Rıza Tevfik'in, Fikret'in inancıyla ilgili toplumda olumlu intibalar oluşsun diye uğraş verdiği, ama bu uğraşın boş bir çaba olduğu şeklinde anlaşılacak ifadeler kullanmaktadır. Babanzâde, bu konudaki iddiasında o denli ileri düzeyde bir yaklaşım ortaya koyar ki Tevfik Fikret'in İslam inancı taşımadığı konusunda bizzat Fikret'in kendisini şahit tutar: "Fakat bu kadar uzun süren sohbetlerimiz esnasında şahsına has bir felsefesi, hele iman u islâmı olduğuna hiç muttali olmadım

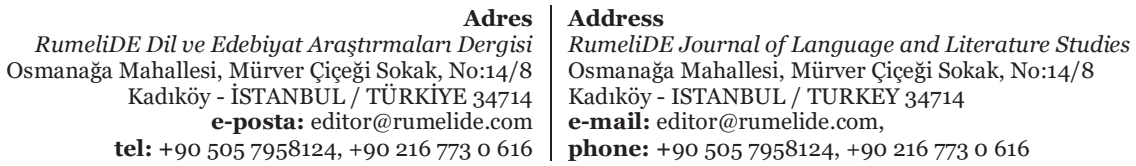


428 / RumeliDE Journal of Language and Literature Studies 2022.26 (February)

A multidimensional approach to the discussion on Tevfik Fikret between Rıza Tevfik and Babanzâde Ahmet Naim / M. Cihangir (pp. 419-430)

dersem ümit etmem ki, taraf-ı âlîlerinden seylî-i tekzîbe maruz kalayım” (Babanzâde Ahmet Naim, 2018: $564)$.

Babanzâde Ahmet Naim, gazetelerde Rıza Tevfik’in Tevfik Fikret’i dinsiz olarak tanımadığı, Fikret’i inanç boyutuyla anlamak için onun yazılı çalışmalarına bakılması gerektiği ve derin bir inceleme sonucunda Fikret'in inançlı bir bir kimse olduğu, ancak ondaki inanç durumunun farklı bir yaklaşım taşıdığı şeklindeki görüşlerine de sert eleştiriler getirerek şu ifadeleri kullanır: "Feylesofçuğum! Fikret büyük şairdir deyiniz, şiiri layık-ı taklit deyiniz; peki deriz. Numune-i fazilet idi deyiniz, birçok kuyud-ı ihtirâziye ile ona da peki deriz. Fakat mü'min idi, müslüman idi demeyiniz, çünkü sizi herkesten evvel kendisi tekzip eder" (Babanzâde Ahmet Naim, 2018: 567-568). Tevfik Fikret'in inancı hakkında bu denli ağır ifadeler kullanan Babanzâde’nin, geçmiş zamanda onunla herhangi bir sorununun olmadığından hareketle konuya tarafsız baktığını ima edecek bir yaklaşım sergiler: "Yine tekrar ederim ki, bizim, Fikret'in şahsı ile hiçbir alışverişimiz yoktur. Bâ-husus benim, evet, benim onunla ne siyasî ne edebî hatta ne de ülfet ü muâşerete ait hiçbir geçmişim, nizâ‘ u hilâfım olduğunu bilmiyorum” (Babanzâde Ahmet Naim, 2018: 566).

Yazar, Rıza Tevfik’in Tevfik Fikret hakkında dile getirdiği görüşleri tartışırken konuyu sadece inanç yönüyle sınırlandırmamaktadır. Onun Robert Koleji’nde görev yapmış olması da Babanzâde açısından olumsuz bir durumdur ve eserde "Amerika bandırası altında, protestanların propaganda ocağında, vatanperverlik makteli olan Rober Kolıc'da [Robert College] vazife kabul ederek” şeklindeki sözlerle bu görevi olumsuz bir şekilde tenkit ettiği saptanmıştır (Babanzâde Ahmet Naim, 2018: 565).

Ayrıca Babanzâde Ahmet Naim, Rıza Tevfik’in konferansında Mehmet Akif ve Sebillüreşad'la ilgili dile getirdiği görüşlerde tarafsız bir yaklaşım sergilemediğini ve dinleyenleri Mehmet Akif ve Sebillüreşad aleyhine galeyana getirdiğini düşünmektedir. Yazar, bu sözlerinden dolayı Rıza Tevfik'e olumsuz eleştiriler getirir (Babanzâde Ahmet Naim, 2018: 576). Dolayısıyla Babanzâde Ahmet Naim, Rıza Tevfik'in Tevfik Fikret hakkında ifade ettiği düşüncelerini olumsuz sözlerle eleştirdiği ileri sürülebilir.

\section{Sonuç}

Rıza Tevfik ile Babanzâde Ahmet Naim arasında cerayan eden Tevfik Fikret tartışmasını sadece bu yazarlar arasında meydana gelmiş ve bitmiş bir tartışma olarak görmemek gerekir. Söz konusu münakaşa öncesinde önemli bir arka plana sahiptir. Bir başka ifadeyle, bahsi geçen tartışmayı anlamak için önceki zamanda Mehmet Akif ile Tevfik Fikret arasında meydana gelmiş münakaşayı da bilmek icap eder. Mehmet Akif ile Tevfik Fikret arasında cerayan etmiş tartışmayı kavramak için ise Osmanlının son zamanlarında ortaya çıkan Doğulu-Batılı, eskici-yenici, muhafazakar-seküler gibi kavramlarla ifade edilen tartışmaları da göz önünde bulundurmak lazımdır. Hatta bu kavramların ortaya çıkmasının ve Osmanlı toplumundaki tartışmalara başlık olmasının arka planında Osmanlının savaşlar kaybetmesine, topraklar yitirmesine yönelik çözüm arayışına bakmak gerekir. Bu arayışa çözüm olarak Batılı ülkelerin gelişmişliğinin kabullenilmesi ve buralara çeşitli gerekçelerle kişi ya da kişilerin gitmesini ya da gönderilmesini gözden geçirmek lazım gelir. Daha sonra söz konusu kimselerin Osmanlıya getirdikleri fikirlerin kaynaklık ettiği ikili toplum ilişkilerine dikkat çekmek şarttır. Dolayısıyla iç içe geçmiş pek çok faktör bağlamında konuyu irdelemek iktiza eder.

Bu bağlamda, Batılı düşünceler taşıyan görüş sahiplerine göre Batılı toplumlar bilimsel, kültürel vb. alanlarda ortaya koydukları başarılarla kendilerini ispat etmişlerdir, bu yüzden Osmanlının yönünü Doğu'dan Batı'ya çevirmesi icap eder. Böylesi fikir sahipleri açısından, temas kurulmasının bir sonucu

\footnotetext{
Adres $\mid$ Address

RumeliDE Dil ve Edebiyat Araşttrmaları Dergisi Osmanağa Mahallesi, Mürver Çiçeği Sokak, No:14/8 Kadıköy - İSTANBUL / TÜRKIYE 34714 e-posta: editor@rumelide.com

RumeliDE Journal of Language and Literature Studies

Osmanağa Mahallesi, Mürver Çiçeği Sokak, No:14/8

Kadıköy - ISTANBUL / TURKEY 34714

e-mail: editor@rumelide.com

tel: +90 5057958124, +902167730616 phone: +90 5057958124, +90 2167730616
} 
olarak Batılı ülkelerde meydana gelen gelişmeler doğrudan ya da dolaylı olarak Osmanlıya geçecek ve Osmanlı kalkınacak, mutlu ve refah düzeyi yüksek bir devlet olacaktır. Ayrıca kayıplar kazanımlara dönüşecek, cephelerde alınan mağlubiyetler ortadan kalkacak ve başarısızlıklar başarıyla yer değiştirecektir.

Bir başka grup ise Osmanlının geri kalma nedenlerini kendi gelenek ve göreneklerine yabancılaşmasından, sosyal, kültürel, dinî vb. özelliklerle olan bağın kopmasından veya ihmal edilmesinden kaynaklandığı düşüncesindedirler. Onlar, bu konulara gereken dikkatin gösterilmesi halinde Osmanlının eski gücünü tekrar elde edeceği, sosyal, siyasal, kültürel, ekonomik, askerî vb. alanda yine başarılı sonuçlar alacağı kanaatindedirler. Bu topluluk, Batılı düşünceler barındıran çözümlere doğrudan karşı çıkmaktadırlar, hatta Osmanlının gerileme nedenlerini Batı'yı referans almasının kaynaklık ettiği inancındadırlar. Böylece Osmanlı toplumunun eski/yerleşik düzeni savunanlar ile yeniyi savunanlar şeklinde ikiye bölündüğü söylenebilir. Bu gibi ayrışmalar, aynı zamanda sert ve ötekileştirici tartışmaların ortaya çıktığı gruplaşmalara yol açar. Rıza Tevfik ile Babanzde Ahmet Naim arasında meydana gelen Tevfik Fikret hakkındaki tartışma da bu bağlamda değerlendirilebilir.

Her iki yazar arasında cereyan eden münakaşa, Rıza Tevfik'in verdiği bir konferansta Tevfik Fikret'le ilgili -özellikle onun inanç yönü hakkında- dile getirdiği görüşlerin Babanzaâde Ahmet Naim tarafından kaleme alınan bir eserle eleştirilmesidir. Dolayısıyla söz konusu tartışma, iki tarafın birbirine karşılık vermesi değil, Rıza Tevfik’in Tevfik Fikret hakkındaki sözlerine Babanzâde Ahmet Naim’in itirazlarıdır.

Tevfik Fikret’i yakından tanıdıklarını dile getiren her iki düşünürün, Fikret’le ilgili ortaya koydukları düşünsel yaklaşımların birbirine tamamen zıt unsurlar barındırdığı tespit edilmiştir. Özellikle Tevfik Fikret'in inancı hakkında zıtlık içeren söylemlerin zirveye çıktığı görülmüştür. Rıza Tevfik, Tevfik Fikret hakkında paylaştığı bilgilerde olumlu bir yaklaşım sergilerken, Babanzâde Ahmet Naim'in olumsuz bir tutum takındığı söylenebilir. Her iki yazarın bu konuda bu denli ayrılığa düşmelerinin temel nedenini, onların düşünce dünyalarında aramak gerekir. Özetle, her iki yazar arasındaki tartışma önceden meydana gelmiş olay ve olgulardan etkilenmiştir. Hatta bu durumun onlardan sonra da devam ettiği ve bu zamanda bile böylesi düşünsel derinlik içeren tartışmaların var olduğu bilinmektedir.

\section{Kaynakça}

Akyüz, Kenan (1947). Tevfik Fikret, Sakarya Basımevi, Ankara.

Akyüz, Kenan (1995). Modern Türk Edebiyatının Ana Çizgileri, İnkılap Kitapevi, İstanbul.

Amin Maalouf (1998). Araplarm Gözüyle Haçh Seferleri, Çev. Mehmet Ali Kılıçbay, Telos Yayıncllık, İstanbul.

Babanzâde Ahmet Naim (2018). "Tevfik Fikret'e Dair Filozof Doktor Riza Tevfik Beyefendiye" Hazırlayan: M. Cüneyt Kaya, Sebîlürreşâd Kütüphanesi Neşriyatı, Babanzâde Ahmet Naim Hayat Eserleri Fikirleri, Editörler: M. Cüneyt Kaya - İsmail Kara, Zeytinburnu Belediyesi Kültür Yayınları, İstanbul, s. $562-576$.

Banarlı, N. Sâmi (1997). Resimli Türk Edebiyat Tarihi II, Milli Eğitim Basımevi, İstanbul.

Barthold, Vasili Viladimiroviç (2004). Rusya'da ve Avrupa'da Oryantalizm, Terc. Kaya Bayraktar Ayşe Meral, Küre Yayınları, İstanbul.

Davişa, Adid (2004). Arap Milliyetçiliği, Çev. Lütfi Yalçın, Literatür Yayınları, İstanbul.

Dawn, C. Ernest (1998). Osmanlıcılıtan Arapçılı̆a, Türkçesi: Bahattin Aydın - Taşkın Temiz, Yöneliş Yayınları, İstanbul.

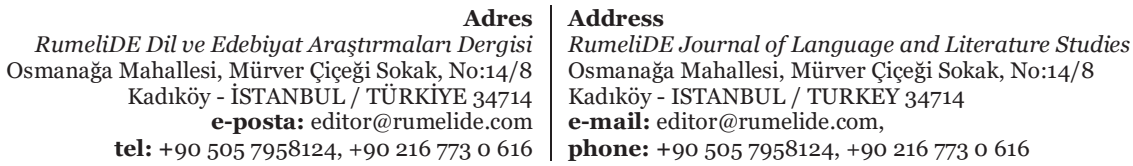


430 / RumeliDE Journal of Language and Literature Studies 2022.26 (February)

A multidimensional approach to the discussion on Tevfik Fikret between Riza Tevfik and Babanzâde Ahmet Naim / M. Cihangir (pp. 419-430)

Ebû-Rabi, M. İbrahim. (2005) Çağdaş Arap Düşüncesi, Çev. İbrahim Kapaklıkaya, Anka Yayınları, İstanbul.

Kaplan, Mehmet (1986). Tevfik Fikret, Kültür ve Turizm Bakanlığı Yayınları, Ankara.

Korkmaz, Ramazan (2007). "Yeni Türk Edebiyatına Giriş”, Yeni Türk Edebiyat 1839-20oo El Kitabı, Editör: Dr. Ramazan Korkmaz, Grafiker Yayıncılık, Ankara, s. 13-40.

Moran, Berna (2012).Türk Romanına Eleştirel Bir Bakış I, İletişim Yayınları, İstanbul.

Okay, Orhan (2011). Sanat ve Edebiyat Yazıları, Dergâh Yayınları, İstanbul.

Ortaylı, İlber (2009). İmparatorluğun En Uzun Yüzyılı, Timaş Yayınları, İstanbul.

Özkırımlı, Atilla (1987) Tevfik Fikret, Cem Yayınevi, İstanbul.

Rıza Tevfik (1945). Tevfik Fikret Hayatı - San'atı - Şahsiyeti, Kenan Matbaası, İstanbul.

Sivri, Medine - Özdemir, Halil (2021). "Victor Hugo ve Tevfik Fikret’in Çocuk Temalı Şiirlerine Karşılaştırmalı Bir Bakış”, Güncel Yaklaşımlar Işığında Karşılaştırmah Edebiyat Çalışmaları, Editör: Dr. Mehmet Cihangir, Efe Akademi Yayınevi, İstanbul. s. 7-38.

Tanpınar, Ahmet Hamdi (2001). 19 uncu Asır Türk Edebiyatı Tarihi, Çağlayan Basımevi, İstanbul.

RumeliDE Dil ve Edebiyat Araşturmaları Dergis Osmanağa Mahallesi, Mürver Çiçeği Sokak, No:14/8 Kadıköy - İSTANBUL / TÜRKIYE 34714 tel: +90 e-posta: editor@rumelide.com
Address

RumeliDE Journal of Language and Literature Studies

Osmanağa Mahallesi, Mürver Çiçeği Sokak, No:14/8

Kadıköy - ISTANBUL / TURKEY 34714

e-mail: editor@rumelide.com,

phone: +90 $5057958124,+902167730616$ 